\title{
MODEL PENENTUAN KOMPETENSI INTI INDUSTRI DAERAH \\ Studi Kasus Kabupaten Bangkalan
}

\author{
Kurniyati Indahsari \\ Fakultas Ekonomi Universitas Trunojoyo Madura \\ E-mail: indahsari_kurniyati@yahoo.com
}

\begin{abstract}
Presidential Decree No. 28/2008 on National Industrial Policy entrust each province/district developing their regional industrial core competency. However, there's no a standard guidelines on how to determine it except the characteristics of the regional core competency. This article tries to explain a model of determining regional industrial core competency using quantitative as well as qualitative approach. Stakeholders met in focus group discussions (qualitative approach) and gave their valuation on grade of competency of some regional industrial products using scoring method (quantitative approach). The result are (1) regional industrial core competence of Bangkalan district are Terung chips, Agel cord, traditional whip, batik, plait a mat and bird cage; and (2) Bangkalan industrial core competence is more characterized by resource based industries than market based industries.
\end{abstract}

Key words: kompetensi industri daerah, sumberdaya dan/atau pasar berbasis industri.

Pengalaman empiris menunjukkan bahwa daerah-daerah yang maju pada umumnya ditandai dengan struktur ekonomi yang didominasi oleh sektor sekunder dan/atau tersier. Pembangunan sektor industri akan menjadi perhatian di daerah tersebut sehingga proses industrialisasi berjalan dengan baik yang dicirikan oleh transformasi struktural perekonomian yang seimbang dan industri terpilih sesuai dengan kompetensi unggulan/khas daerah. Transformasi struktural perekonomian tersebut ditandai oleh semakin besarnya kontribusi sektor sekunder dan tersier terhadap Produk Domestik Regional Bruto (PDRB) seiring dengan menurunnya kontribusi sektor primer. Sementara itu, transformasi struktural yang seimbang berarti pergeseran kontribusi sektor-sektor PDRB tersebut diiringi pula dengan pergeseran proporsi tenaga kerja yang bekerja pada sektor-sektor tersebut. Artinya, jika saat ini kontribusi terhadap PDRB telah didominasi oleh sektor sekunder dan tersier, maka seharusnya proporsi pekerja di kedua sektor tersebut juga harus dominan. 
Selain itu, proses industrialisasi akan berjalan dengan baik jika industri terpilih sesuai/bisa menunjukkan kompetensi unggulan/khas daerah. Pemilihan basis dan detail sektor industri dilakukan secara hati-hati dengan pertimbangan masalah yang dihadapi sekarang dan yang akan datang. Parameter arsitektur industri yang dipilih adalah memiliki daya saing tinggi, merupakan produk unggulan daerah sehingga bisa didorong menjadi kompetensi inti industri daerah yang pada akhirnya bisa menjadi industri andalan masa depan.

Dalam kebijakan pembangunan nasional, khususnya untuk pengembangan industri nasional, Pemerintah Indonesia telah mengeluarkan Peraturan Presiden RI (Perpres) No. 28 Tahun 2008 tentang Kebijakan Industri Nasional pada tanggal 7 Mei 2008. Kebijakan ini dibuat untuk memberikan arahan pada setiap upaya pengembangan industri nasional sehingga target pembangunan industri nasional jangka panjang (tahun 2025) dapat tercapai. Perpres ini akan menjadi pedoman operasional pemerintah pusat dan daerah dalam mengembangkan industri nasional dan daerah, serta menjadi tolak ukur kemajuan dan keberhasilan strategi pengembangan industri.

Perpres no. 28 Tahun 2008 ini juga menjadi dasar pemberian fasilitas dan insentif pemerintah untuk berbagai upaya penanaman modal sesuai pasal 19 Undang-Undang Nomor 25 Tahun 2007 tentang Penanaman Modal. Pemerintah hanya akan memberikan fasilitas dan insentif untuk penanaman modal yang sesuai dengan kebijakan industri nasional yang ditetapkan pemerintah. Jenis industri yang sesuai dengan kebijakan industri nasional adalah industri yang dikategorikan sebagai industri prioritas, prioritas tinggi, industri pionir dan kompetensi inti daerah.

Dalam konteks pelaksanaan pembangunan daerah (otonomi daerah), Perpres no. 28 Tahun 2008 ini mengamanatkan setiap daerah untuk mengembangkan kompetensi inti industri daerah. Kompetensi Inti Industri Daerah adalah sekumpulan keunggulan atau keunikan sumberdaya termasuk sumber daya alam dan kemampuan suatu daerah untuk membangun daya saing dalam rangka mengembangkan perekonomian Propinsi dan Kabupaten/Kota menuju kemandirian. Pemerintah daerah dituntut untuk menumbuhkan industri baru yang 
potensial yang berbasis pada potensi sumber daya nasional, yang memiliki potensi berkembang yang tinggi, khususnya yang berbasis SDA (Sumber Daya Alam) terbarukan dan SDM berpengetahuan maupun keunggulan aspek lain (kondisi geografi, luas bentang wilayah, kekayaan budaya, dan sebagainya) dalam rangka menyuburkan industri.

Hingga saat ini belum ada suatu pedoman yang bisa mengarahkan setiap daerah untuk menentukan kompetensi inti industrinya. Perpres tersebut hanya memberikan ciri-ciri industri yang bisa dikategorikan sebagai kompetensi inti. Karenanya, tulisan ini berusaha menguraikan sebuah model penentuan kompetensi inti industri daerah yang memadukan pendekatan kauntitatif dan kualitatif, dengan studi kasus di Kabupaten Bangkalan.

\section{TINJAUAN PUSTAKA}

\section{Konsep Kompetensi Inti Industri}

Aurino (2008) mengemukakan bahwa di beberapa studi, pengertian Kompetensi Inti Daerah adalah keunggulan daerah yang Unik meliputi aspek Ketrampilan Manusia, Sumber Daya Alam, Lingkungan, Budaya, dan prospek Pasar, baik untuk produk primer maupun produk olahan. Kompetensi inti daerah dapat dibedakan atas kompetensi produk primer dan produk olahan. Produk primer meliputi aspek Manusia, Sumber Daya Alam, Lingkungan, Budaya, prospek Pasar. Produk olahan meliputi aspek Produk, Eko Wisata, Budaya, Teknologi, Infrastruktur,dan Pasar. Sementara itu, ciri-ciri kompetensi inti daerah terdiri dari 3, yaitu (1) Memiliki akses potensial ke berbagai pasar - kompetensi inti daerah harus dapat mengembangkan produk atau jasa baru; (2) harus memciptakan kontribusi nyata untuk mendapatkan manfaat produk akhir; dan (3) memiliki sesuatu yang sulit ditiru oleh kompetitor lain/ daerah lain, dengan kata lain bersifat unik.

Peraturan Presiden (Perpres) no. 28 tahun 2008, mengemukakan pengertian Kompetensi Inti Industri Daerah sebagai sekumpulan keunggulan atau keunikan sumberdaya termasuk sumber daya alam dan kemampuan suatu daerah untuk membangun daya saing dalam rangka mengambangkan perekonomian Propinsi dan 
Kabupaten/Kota menuju kemandirian. Indutri yang bisa dipertimbangkan sebagai kompetensi inti industri daerah adalah industri dengan karakteristik antara lain:

a) Merupakan produk unggulan di daerah atau yang memiliki potensi sebagai unggulan;

b) Memiliki keterkaitan yang kuat (baik keterkaitan horizontal maupun keterkaitan vertikal);

c) Produk memiliki keunikan lokal;

d) Tersedianya sumber daya manusia dengan keterampilan yang memadai.

\section{Penentuan Kompetensi Inti Industri Daerah}

Perpres no. 28 tahun 2008 memberikan gambaran tentang tahapan perencanaan atau membangun kompetensi inti daerah untuk kabupaten/kota, yaitu melalui:

(1) Analisis potensi sumber daya yang dimiliki daerah

(2) Pemilihan komoditi unggulan yang akan dikembangkan

(3) Penetapan dan penyusunan strategi kompetensi inti industri daerah

(4) Pembangunan pusat keunggulan industri yang menjadi kompetensi inti industri daerah

(5) Peningkatan keterampilan dan keahlian sumber daya manusia

(6) Peningkatan efektivitas pengembangan IKM di sentra dengan pendekatan One Village One Product (OVOP).

Sementara itu, untuk penentuan kompetensi inti industri dilaksanakan workshop dan focus group discussion (FGD), seperti yang dilakukan oleh Pemerintah Kota Singkawang (Sekda Kota Sinkawang, 2008). Workshop dan FGD diikuti berbagai unsur stakeholder baik dari Departemen Perindustrian RI, Unit Kerja Teknis Pemkot Singkawang yang terkait dengan sektor ekonomi, akademisi serta pelaku usaha industri dari berbagai jenis komoditi.

\section{Kompetensi Inti Industri Daerah dan One Village One Product (OVOP)}

Konsep OVOP digagas oleh Dr Morihiko Hiramatsu dan telah berhasil dikembangkan di Jepang sejak tahun 1979. Wanadriko (2008) mendefinisikan Satu 
Desa Satu Product atau One Village One product sebagai pendekatan pengembangan potensi daerah di satu wilayah unuk menghasilkan satu produk kelas global yang unik khas daerah dengan memanfatkan sumber daya lokal. Satu desa sebagaimana dimaksud dapat dperluas menjadi kecamatan, kabupaten/kota, maupun kesatuan wilayah lainnya sesuai dengan potensi dan skala usaha secara ekonomis.

Wanandriko (2008) juga mengemukakan bahwa tujuan OVOP adalah untuk menggali dan mempromosikan produk inovatif dan kreatif lokal, dari sumber daya, yang bersifat unik khas daerah, bernilai tambah tinggi, dengan tetap menjaga kelestarian lingkungan, memiliki image dan daya saing yang tinggi. Sementara kriteria produk yang dikembangkan dalam OVOP adalah (1) Produk unggulan daerah dan/atau produk kompetensi inti daerah; (2) Unik khas budaya dan keaslian local; (3) berpotensi pasar domestik dan ekspor; (4) Bermutu dan berpenampilan baik; (5) Diproduksi secara kontinyu dan konsisten. Produk-produk tersebut dapat berupa produk makanan olahan berbasis hasil pertanian dan perkebunan, produk aneka minuman dari hasil pengolahan hasil pertanian dan perkebunan, Produk hasil tenun atau konveksi khas masyarakat local, produk kebutuhan rumah tangga termasuk produk dekoratif atau interior, Produk barang seni dankerajinan termasuk produk cinderamata, maupun produk herbal dan minyak atsiri khas masyarakat lokal

\section{METODE PENELITIAN}

\section{Tahapan Kegiatan}

Penentuan kompetensi inti industri daerah dengan kasus di Kabupaten Bangkalan ini dilakukan melalui beberapa tahapan. Pertama, memilih industriindustri di Kabupaten Bangkalan hasil kompilasi yang memiliki unit usaha minimal 20. Hanya industri yang telah memiliki total unit usaha minimal 20 se Kabupaten Bangkalan yang akan dianalisis lebih lanjut apakah memenuhi kriteria kompetensi inti industri atau tidak. Hal ini didasarkan pertimbangan bahwa: (1) industri atau usaha (yang umumnya berskala mikro atau kecil) akan dapat bersaing, baik di pasar input maupun output, jika mereka memiliki daya tawar yang tinggi. Selama mereka 
bergerak sendiri, maka daya tawar akan rendah. Namun, daya tawar dapat ditinggikan jika industri/usaha serupa bergabung dalam sebuah kelembagaan dan secara bersama-sama memperjuangkan usaha mereka; dan (2) hingga saat ini kelembagaan umum yang menampung para pengusaha kecil dan mikro ini adalah koperasi. Menurut Undang-undang No. 25 tahun 1992, tanggal 21 Oktober 1999, tentang Perkoperasian, khususnya Pasal 6, pembentukan koperasi dapat dilakukan jika ada minimal 20 anggota.

Kedua, berbekal informasi tentang industri-industri yang terpilih dan variabel/kriteria dasar penentuan kompetensi inti industri, dilakukan focus group discussion dan/atau wawancara mendalam dengan para stakeholders perindustrian di Kabupaten Bangkalan, khususnya di Dinas Perindustrian dan Perdagangan. Selain informasi kualitatif terkait potensi, permasalahan hingga arah kebijakan pengembangan industri, hasil tahap ini adalah skor kompetensi setiap industri terpilih, baik untuk masing-masing variabel maupun total, berdasarkan pendapat responden yang diukur dengan Teknik Skoring (lihat sub bab 3.2.).

Ketiga, dengan asumsi bahwa setiap variabel/kriteria memiliki bobot yang sama dalam menentukan kompetensi inti, maka skor total kompetensi setiap industri diperoleh dengan menjumlahkan skor seluruh variable. Industri dengan total skor yang tinggi adalah kompetensi inti industri kabupaten Bangkalan. Belum ada patokan dalam penentuan skor minimal sehingga sebuah industri dikatakan sebagai kompetensi inti industri Kabupaten Bangkalan. Karenanya, penentuan batas dilakukan juga bersama saat diskusi dan/atau wawancara mendalam dengan para stakeholders di atas.

\section{Teknik Skoring Variabel Kompetensi Inti Industri Daerah}

Dari ciri-ciri kompetensi inti industri daerah seperti yang diuraikan dalam Tinjauan Pustaka diturunkanlah variabel-variabel baru yang akan digunakan sebagai alat ukur. Teknik skoring dipergunakan untuk mempermudah pengukuran. Di sini diberlakukan aturan bahwa semakin tinggi skor, maka semakin tinggi pula tingkat kompetensi inti dalam variabel yang dimaksud. Tabel 1. memperlihatkan 
variabel-variabel turunan yang digunakan sebagai dasar dalam penentuan kompetensi inti industri di Kabupaten Bangkalan beserta skor-nya:

\section{Tabel 1. Variabel dan Skor PenentuanKompetensi Inti Industri Daerah}

\begin{tabular}{|c|c|}
\hline Variabel & SKOR dan ARTINYA \\
\hline $\begin{array}{l}\text { Kekhasan / tingkat } \\
\text { keunikan lokal }\end{array}$ & $\begin{array}{l}0 \text { Jika tidak khas, artinya produk industri tersebut dapat ditemui di } \\
\text { mana pun } \\
1 \text { jika cukup khas, artinya produk industri tersebut dapat ditemui di } \\
\text { banyak daerah lain, namun ada karakter khusus produk yang khas } \\
\text { Bangkalan } \\
2 \text { jika khas Bangkalan, yaitu produk banyak ditemui di Kabupaten } \\
\text { Bangkalan meskipun ada (namun tidak banyak) daerah lain yang } \\
\text { juga memproduksinya dan produk memiliki karakter yang } \\
\text { membedakannya dengan produk yang sama di daerah. }\end{array}$ \\
\hline $\begin{array}{l}\text { Asal bahan baku } \\
\text { produksi/industri }\end{array}$ & $\begin{array}{ll}0 & \text { jika seluruhnya berasal dari luar Bangkalan } \\
1 & \text { jika sebagian besar (>50\%) berasal dari luar Bangkalan } \\
2 & \text { jika sebagian besar (>50\%) berasal dari Bangkalan (lokal) } \\
3 & \text { jika seluruhnya (100\%) beasal dari Bangkalan (lokal) }\end{array}$ \\
\hline $\begin{array}{l}\text { Asal tenaga kerja } \\
\text { (pekerja) dalam } \\
\text { proses produksi }\end{array}$ & $\begin{array}{ll}0 & \text { jika seluruh pekerja berasal dari luar Bangkalan } \\
1 & \text { jika sebagian besar pekerja (>50\%) berasal dari luar Bangkalan } \\
2 & \text { jika sebagian besar pekerja (>50\%) berasal dari Bangkalan } \\
3 & \text { jika seluruh pekerja berasal/direkrut dari Bangkalan (pekerja } \\
\text { lokal) }\end{array}$ \\
\hline $\begin{array}{l}\text { Kaderisasi } \\
\text { keterampilan/skill } \\
\text { SDM dalam proses } \\
\text { produksi. }\end{array}$ & $\begin{array}{ll}0 & \text { keterampilan hanya dimiliki pekerja yang ada saat ini dan } \\
& \text { tidak/belum ada upaya kaderisasi keterampilan pada tenaga kerja } \\
& \text { generasi berikutnya } \\
1 & \text { keterampilan hanya dimiliki pekerja yang ada saat ini dan telah } \\
& \text { ada upaya kaderisasi keterampilan pada tenaga kerja generasi } \\
& \text { berikutnya, namun terbatas } \\
2 & \text { Semua orang bisa melanjutkannya dengan mudah/ kaderisasi } \\
\text { tidak terbatas }\end{array}$ \\
\hline $\begin{array}{l}\text { Inovasi Teknologi } \\
\text { produksi }\end{array}$ & $\begin{array}{ll}0 & \text { Belum/tidak pernah ada inovasi teknologi dalam proses produksi } \\
1 & \text { Ada potensi/kemungkinan/rencana penggunaan }\end{array}$ \\
\hline
\end{tabular}




\begin{tabular}{|c|c|c|}
\hline & 2 & $\begin{array}{l}\text { teknologi/inovasi-inovasi baru dalam produksi } \\
\text { Menggunakan teknologi dan/atau inovasi-inovasi baru dalam } \\
\text { proses produksi }\end{array}$ \\
\hline $\begin{array}{l}\text { Kombinasi SDM } \\
\text { dan kapital dalam } \\
\text { proses produksi }\end{array}$ & 0 & $\begin{array}{l}\text { jika padat karya atau padat modal } \\
\text { jika relatif seimbang antara keduanya (mampu menyerap tenaga } \\
\text { kerja sekaligus tetap bisa memanfaatkan teknologi) }\end{array}$ \\
\hline $\begin{array}{l}\text { Keberadaan dan } \\
\text { peran kelembagaan }\end{array}$ & 0 & $\begin{array}{l}\text { jika tidak/ belum ada paguyuban/koperasi/kelembagaan yang } \\
\text { menaunginya } \\
\text { jika telah ada kelembagaan yang menaunginya, namun masih pasif } \\
\text { jika ada kelembagaan yang menaunginya dan aktif }\end{array}$ \\
\hline $\begin{array}{l}\text { Ketersediaan pasar } \\
\text { (sasaran pemasaran) }\end{array}$ & 0 & $\begin{array}{l}\text { Belum punya pasar } \\
\text { Sudah punya pasar, tapi terbatas } \\
\text { Sudah punya pasar yang luas }\end{array}$ \\
\hline $\begin{array}{l}\text { Packaging/kemasan } \\
\text { produk }\end{array}$ & 2 & $\begin{array}{l}\text { Belum terkemas } \\
\text { Terkemas namun belum terdaftar (belum memiliki nomor } \\
\text { registrasi dari Departemen Kesehatan, BPOM atau Dinas } \\
\text { Perindustrian dan Perdagangan) } \\
\text { Terkemas dan terdaftar (telah memiliki nomor registrasi dari } \\
\text { Departemen Kesehatan BPOM atau Dinas Perindustrian dan } \\
\text { Perdagangan) }\end{array}$ \\
\hline Segmen Pasar & 0 & $\begin{array}{l}\text { Hanya golongan tertentu (sangat sempit) } \\
\text { Golongan tertentu tapi lebih luas } \\
\text { Semua golongan }\end{array}$ \\
\hline $\begin{array}{l}\text { Daya tawar pelaku } \\
\text { industri (produsen) } \\
\text { di pasar input }\end{array}$ & 0 & $\begin{array}{l}\text { Produsen/pelaku industri adalah penerima (tidak bisa } \\
\text { menentukan) harga input produksi } \\
\text { Memiliki daya tawar yang sama antara produsen dan konsumen } \\
\text { (harga input ditentukan bersama antara pelaku industri dan } \\
\text { pembeli) } \\
\text { Produsen/pelaku industri adalah penentu harga input }\end{array}$ \\
\hline $\begin{array}{l}\text { Daya tawar } \\
\text { produsen di pasar } \\
\text { output }\end{array}$ & 0 & $\begin{array}{l}\text { Produsen/pelaku industri adalah penerima (tidak bisa } \\
\text { menentukan) harga produk } \\
\text { Memiliki daya tawar yang sama antara produsen dan konsumen } \\
\text { (harga produk ditentukan bersama antara pelaku industri dan }\end{array}$ \\
\hline
\end{tabular}




\begin{tabular}{|c|c|}
\hline & $\begin{array}{ll} & \text { pembeli) } \\
2 & \text { Produsen/pelaku industri adalah penentu harga produk }\end{array}$ \\
\hline $\begin{array}{l}\text { Jumlah sektor hulu } \\
\text { terkait }\end{array}$ & $\begin{array}{l}\text { to tidak memiliki sektor hulu. Artinya, produk adalah produk primer } \\
\text { (hasil pertanian). Sesuai dengan definisi / cakupan industri } \\
\text { pengolahan, maka sektor industri minimal akan memiliki } 1 \text { sektor } \\
\text { hulu, yaitu sektor pertanian. } \\
\text {.... Isi dengan angka berapa banyak sektor hulunya }\end{array}$ \\
\hline $\begin{array}{l}\text { Jumlah sektor hilir } \\
\text { terkait }\end{array}$ & $\begin{array}{l}\text { 0; tidak memiliki sektor hilir, produk langsung dinikmati konsumen } \\
\text { akhir tanpa perantaraan pihak lain, misalnya pelaku sektor } \\
\text { perdagangan. } \\
\text {... Isi dengan angka berapa banyak sektor hilirnya }\end{array}$ \\
\hline
\end{tabular}

\section{HASIL DAN PEMBAHASAN}

\section{Database Industri di Kabupaten Bangkalan}

Diakui oleh semua pihak terkait pembangunan industri bahwa Kabupaten Bangkalan belum memiliki database industri yang lengkap. Industri yang tercatat hanyalah industri formal, artinya yang memiliki ijin usaha. Dinas terkait industri, dalam hal ini Disperindag dan Koperasi UMKM melakukan pengumpulan data industri - khususnya industri mikro, kecil dan menengah - secara terpisah, sesuai dengan kepentingan program di masing-masing dinas. Karenanya, tidak mengherankan jika jenis dan jumlah industri yang terkumpul akan berbeda.

Untuk kepentingan studi ini, dilakukan kompilasi berbagai data industri yang ada di Bangkalan, khususnya yang terkategori industri mikro, kecil dan menengah. Kompilasi dilakukan sedemikian rupa sehingga setiap sumberdata saling melengkapi dan meminimalisasi tumpang tindih. Sumberdata yang digunakan adalah Direktori Perusahaan Industri Kecil Menengah Kabupaten Bangkalan Tahun 2008; Data Sentra Industri Kecil dan Menengah (IKM) Kabupaten Bangkalan Tahun 2008; dan Daftar Industri Mikro, Kecil dan Menengah (IMKM) dalam Studi Pengembangan IMKM milik Dinas Koperasi UMKM Kabupaten Bangkalan Tahun 2008; dan data bagian Industri dalam Bangkalan dalam Angka 
Tahun 2009 di bagian Industri. Rekapitulasi hasil kompilasi ditunjukkan dalam Tabel 2.

Tabel 2. Jenis dan Jumlah Unit Industri per Kecamatan di Kabupaten Bangkalan Tahun 2008

\begin{tabular}{|c|c|c|c|c|c|c|c|c|c|}
\hline \multirow[b]{2}{*}{ Kecamatan } & \multicolumn{9}{|c|}{ Kelompok Jenis Industri* } \\
\hline & $\mathbf{A}$ & B & $\mathrm{C}$ & $\mathrm{D}$ & $\mathbf{E}$ & $\mathbf{F}$ & G & $\mathbf{H}$ & Total \\
\hline Arosbaya & 53 & 1 & 3 & & & 4 & & 3 & 64 \\
\hline Bangkalan & 85 & 6 & 12 & 6 & 3 & 12 & & 172 & 296 \\
\hline Blega & 74 & & 163 & & 3 & & & 2 & 242 \\
\hline Burneh & 167 & & & 1 & 2 & 3 & & 5 & 178 \\
\hline Galis & 1 & & 5 & & & & & 30 & 36 \\
\hline Geger & & & 8 & 1 & 65 & 1 & & 2 & 77 \\
\hline Kamal & 66 & & 66 & & 4 & & & 13 & 149 \\
\hline Klampis & 109 & & 9 & 1 & 79 & 1 & & 1 & 200 \\
\hline Kokop & & 21 & 528 & & 63 & & & & 612 \\
\hline Konang & 7 & & 213 & & 23 & 4 & & 1 & 248 \\
\hline Kwanyar & 205 & 6 & 9 & & 59 & & & 6 & 285 \\
\hline Labang & 6 & 1 & 6 & & 5 & 1 & 5 & & 24 \\
\hline Modung & & & 1 & & 1 & & & & 2 \\
\hline Sepulu & 32 & 1 & 69 & 1 & 2 & 2 & & 1 & 108 \\
\hline Socah & 198 & 4 & 140 & & 202 & 1 & 3 & 6 & 554 \\
\hline Tanah Merah & 24 & 42 & 71 & 4 & 2 & 4 & & 5 & 152 \\
\hline Tanjung Bumi & 149 & 1313 & 196 & & 59 & 1 & & 4 & 1722 \\
\hline Tragah & 46 & 28 & 21 & & 11 & 18 & & & 124 \\
\hline
\end{tabular}

*) Kelompok Industri: A. Makanan, Minuman, tembakau; B. Tekstil, Barang Kulit, Alas Kaki; C. Barang Kayu dan Hasil Hutan; D. Pupuk, Kimia, barang dari Karet; E. Semen, bahan galian non logam; F. Logam dasar, besi, baja; G. Alat Angkut, Mesin dan Peralatan; H. Barang Lainnya

Sumber: Kompilasi Data Berbagai sumber

\section{Kompetensi Inti Industri Kabupaten Bangkalan}

Hasil penentuan kompetensi inti industri Kabupaten Bangkalan dengan teknik skoring dapat dilihat pada Tabel 3. Dari seluruh industri yang ada di Kabupaten Bangkalan, terdapat 30 jenis industri yang jumlah total unit usaha se 
Kabupaten Bangkalan minimal 20 unit. Rinciannya, 12 jenis industri makanan dan minuman; 3 jenis industri tekstil, barang kulit dan alas kaki; 8 jenis industri barang kayu dan hasil hutan; 5 jenis industri semen, bahan galian non semen dan 2 jenis industri barang lainnya.

Analisis variabel/kriteria kompetensi inti terhadap ke-30 jenis industri tersebut memperlihatkan bahwa (1) hanya 6 industri yang produknya memiliki kekhasan yang tinggi, yaitu Kripik/krupuk Terong, Batik Tulis, Daun Pocok/tali agel, tikar, anyaman tikar dan pecut; (2) hampir seluruh jenis industri mendapatkan bahan bakunya dari daerah sekitar (lokal). Hanya industri tekstil yang sebagian besar bahan bakunya berasal dari luar Bangkalan, karena memang tidak ada industri kain di Kabupaten Bangkalan yang produknya bisa dijadikan input inustriindustri ini. Demikian pula dengan industri jasa lassery, mebel kayu dan ukirannya, beberapa jenis industri makanan (ada bahan baku yang dipenuhi dari luar Bangkalan); (3) Sebagian besar pekerja industri di Kabupaten Bangkalan adalah orang Madura. Hanya ada beberapa jenis industri yang dirintis dan/atau mempekerjakan orang luar Bangkalan dengan pertimbangan keahliannya/kebersediaannya; (4) Sebagian besar industri di Kabupaten Bangkalan adalah industri rumahtangga yang menurun dari generasi sebelumnya. Karenanya, kaderisasi keterampilan pekerja yang digunakan dalam proses produksi terbatas pada keluarga dan/atau pekerjanya saja. Umumnya, kaderisasi terbatas pada industri makanan dan minuman karena ada resep tertentu yang terkadang tidak bisa diketahui oleh pihak luar karena dianggap sebuah resep rahasia. Pengecualian pada beberapa industri kerajinan dari kayu dan hasil hutan - seperti tali agel, tikar, sangkar burung, ukiran/mebel. Di Kabupaten Bangkalan, keterampilan dalam proses produksi di industri tersebut dimiliki oleh sebagian besar penduduk yang bermukim di desa di mana industri ini banyak ditemukan. Siapa pun dapat mempelajari keterampilan tersebut asal ada kemauan. Pada industri batik tulis, keterampilan membatik bisa saja dipelajari siapa saja, namun kekhasan batik tulis Bangkalan terletak pada pewarnaan yang hingga saat ini masih menjadi 'rahasia' pembatik. Sementara itu, jika suatu saat generasi penerus tidak bisa meneruskan dengan berbagai alasan, maka industri ini dapat terancam keberlanjutannya; (5) 
tentang penggunaan teknologi dan/atau inovasinya, diakui bahwa seluruh industri di Kabupaten Bangkalan umumnya masih tradisional. Meski telah ada inovasiinovasi baru dalam proses produksi, namun kendala umum adalah masyarakat/pelaku industri relative sulit menerima 'sesuatu yang baru' dengan berbagai alasan; (6) Kombinasi pemakaian mesin dan tenaga kerja seluruh industri di Kabupaten Bangakalan relative berimbang. Mesin yang dimaksud di sini pun masih terkategori yang konvensional/tradisional yang tidak membutuhkan modal besar; (7) Sehubungan dengan kelembagaan, telah ada beberapa koperasi, paguyuban atau pun assosiasi di Kabupaten Bangkalan yang akan merangkul para pengrajin/pelaku industri. Sayangnya, tidak semua pelaku industri ini aktif bergabung. Umumya, hanya pelaku industri yang relative 'besar' saja yang bergabung dan pro aktif secara bersama-sama mengembangkan usahanya. Sebagian besar masih pasif; (8) Seluruh produk jenis industri yang dianalisis umumnya telah memiliki pasar, namun masih sangat terbatas. Batasan yang dimaksud adalah lokal atau ekspor. Namun, masih sulit ditemui produk industri di Bangkalan yang memiliki pasar luas, yaitu lokal, nasional, dan internasional; (9) Industri di kabupaten Bangkalan umumya masih belum berkembang, sehingga kalupun produk dikemas, maka kemasan sangat sederhana. Untuk beberapa produk industri yang saat ini telah diklaim sebagai produk unggulan Bangkalan, seperti Batik dan beberapa produk industri makanan dan minuman memang telah dikemas (walau tetap masih sederhana) dan telah memiliki ijin; (10) Untuk produk industri makanan dan minuman, umumnya memiliki segmen pasar yang luas (semua golongan). Namun untuk beberapa produk yang terkategori cukup mahal - katakan saja batik tulis, mebel ukiran, beberapa jenis sangkar burung, memang tidak semua golongan mampu mengaksesnya. Walaupun demikian, industri-industri ini juga memproduksi produk untuk golongan menengah ke bawah walau dalam porsi yang terbatas; (11) Umumnya pelaku industri di pasar input maupun output masih memiliki daya tawar, namun tidak tinggi; (12) Terkait dengan sektor-sektor hulu yang terkait, umumnya industri yang ada di Bangkalan memiliki dua sektor hulu, yaitu sektor pertanian dan perdagangan. Artinya, mereka hanya mengolah hasil pertanian yang mereka beli dari pedagang dan/atau pengepul. Namun, ada juga 
industri yang mengolah langsung input yang berasal dari pertanian (jumlah sektor hulu =1). Ini berarti bahwa pelaku industri - umumnya di pengrajin adalah sekaligus petani yang mengahsilkan produk pertanian bahan baku industrinya; (13) Hingga saat ini industri-industri yang ada di Bangkalan masih memiliki sektor hilir yang pendek. Umumnya produk adalah produk jadi yang siap dipasarkan ke konsumen. Hanya beberapa yang produknya adalah bahan setengah jadi. Pengolahan lanjutannya pun umumnya tidak dilakukan di Bangkalan, namun di luar Bangkalan, seperti pengemasan atau menjadikannya produk akhir yang lebih menarik (memiliki nilai tambah yang lebih tinggi).

Total skor yang menunjukkan tingkat kompetensi industri dari ke-30 jenis industri memperlihatkan variasi yang rendah. Artinya, belum ada industri yang benar-benar menyolok/berbeda jauh skor kompetensinya dari yang lain. Skor yang paling tinggi (skor ideal) jika mengikuti teknik skor yang telah ditentukan dalam studi ini adalah minimal 29. Itu pun diasumsikan jumlah sektor hulu dan hilir yang terkait masing-masing dua. Dengan demikian, tingkat kompetensi inti industri Kabupaten Bangkalan masih cukup jauh dari skor idealnya, karena skor tertinggi adalah 23. 
Tabel 3. Skor Variabel Kompetensi Inti Industri Kabupaten Bangkalan

\begin{tabular}{|c|c|c|c|c|c|c|c|c|c|c|c|c|c|c|c|c|}
\hline \multirow[b]{2}{*}{ Industri } & \multirow[b]{2}{*}{$\begin{array}{c}\text { Tot } \\
\text { Unit } \\
\text { Indus } \\
\text {-tri }\end{array}$} & \multicolumn{14}{|c|}{ Variabel/Dasar Pertimbangan Kompetensi Inti Industri } & \multirow[b]{2}{*}{$\begin{array}{l}\text { Total } \\
\text { skor }\end{array}$} \\
\hline & & $\begin{array}{c}\text { Kekha } \\
\text {-san }\end{array}$ & $\begin{array}{l}\text { Ba- } \\
\text { han } \\
\text { bak } \\
\text { u }\end{array}$ & $\begin{array}{l}\text { Asal } \\
\text { Peker } \\
\text {-ja }\end{array}$ & $\begin{array}{l}\text { Kade } \\
\text { risasi } \\
\text { SDM }\end{array}$ & $\begin{array}{l}\text { Tekno- } \\
\text { logi/ } \\
\text { Inovasi }\end{array}$ & $\begin{array}{l}\text { Komb } \\
\text { TK Vs } \\
\text { Mesin }\end{array}$ & $\begin{array}{l}\text { Kelem- } \\
\text { bagaan }\end{array}$ & Pasar & $\begin{array}{l}\text { Packa } \\
\text { ging }\end{array}$ & $\begin{array}{l}\text { Seg } \\
\text { me } \\
\text { n }\end{array}$ & $\begin{array}{c}\text { Dy } \\
\text { Ta } \\
\text { war } \\
\text { in- } \\
\text { put }\end{array}$ & $\begin{array}{c}\text { Dy } \\
\text { Ta } \\
\text { war } \\
\text { out } \\
\text { put }\end{array}$ & $\begin{array}{l}\text { Sek- } \\
\text { tor } \\
\text { hulu }\end{array}$ & $\begin{array}{l}\text { Sek- } \\
\text { tor } \\
\text { hilir }\end{array}$ & \\
\hline \multicolumn{17}{|c|}{ A. Makanan, Minuman, tembakau } \\
\hline $\begin{array}{l}\text { Pengasapan/pengeringan } \\
\text { ikan }\end{array}$ & 196 & 1 & 3 & 2 & 1 & 1 & 1 & 1 & 1 & 1 & 2 & 1 & 1 & 3 & 1 & 20 \\
\hline Emping Mlinjo & 187 & 1 & 2 & 2 & 1 & 1 & 1 & 1 & 1 & 1 & 2 & 1 & 1 & 2 & 1 & 18 \\
\hline Petis & 109 & 1 & 3 & 3 & 1 & 1 & 1 & 1 & 1 & 1 & 2 & 1 & 1 & 2 & 1 & 20 \\
\hline Krupuk Udang & 108 & 1 & 2 & 2 & 1 & 1 & 1 & 1 & 1 & 1 & 2 & 1 & 1 & 2 & 1 & 18 \\
\hline Terasi & 108 & 1 & 2 & 2 & 1 & 1 & 1 & 1 & 1 & 2 & 2 & 1 & 1 & 2 & 1 & 19 \\
\hline Tempe & 82 & 0 & 0 & 3 & 1 & 1 & 1 & 1 & 1 & 0 & 2 & 1 & 1 & 2 & 1 & 15 \\
\hline Wingko & 74 & 1 & 2 & 2 & 1 & 1 & 1 & 1 & 1 & 1 & 2 & 1 & 1 & 2 & 1 & 18 \\
\hline Kripik Terong & 66 & 2 & 3 & 3 & 1 & 1 & 1 & 1 & 1 & 2 & 2 & 1 & 1 & 2 & 1 & 22 \\
\hline Tepung & 39 & 0 & 3 & 2 & 1 & 1 & 1 & 1 & 1 & 1 & 2 & 1 & 1 & 2 & 1 & 18 \\
\hline Garam & 25 & 1 & 3 & 2 & 1 & 1 & 1 & 1 & 1 & 2 & 2 & 1 & 1 & 1 & 1 & 19 \\
\hline Telur Asin & 23 & 1 & 2 & 2 & 1 & 1 & 1 & 1 & 1 & 2 & 2 & 1 & 1 & 1 & 1 & 18 \\
\hline Krupuk Kwanyar & 21 & 1 & 3 & 3 & 1 & 1 & 1 & 1 & 1 & 1 & 2 & 1 & 1 & 1 & 1 & 19 \\
\hline \multicolumn{17}{|c|}{ B. Tekstil, Barang Kulit, Alas Kaki } \\
\hline Batik tulis & 975 & 2 & 1 & 3 & 1 & 1 & 1 & 1 & 1 & 2 & 2 & 1 & 1 & 3 & 1 & 21 \\
\hline
\end{tabular}




\begin{tabular}{|c|c|c|c|c|c|c|c|c|c|c|c|c|c|c|c|c|}
\hline Konveksi & 53 & 0 & 0 & 2 & 1 & 1 & 1 & 1 & 1 & 2 & 2 & 1 & 1 & 2 & 2 & 17 \\
\hline Bordir & 28 & 0 & 0 & 2 & 1 & 1 & 1 & 1 & 1 & 2 & 2 & 1 & 1 & 2 & 2 & 17 \\
\hline \multicolumn{17}{|c|}{ C. Barang Kayu dan Hasil Hutan } \\
\hline Anyaman pandan & 336 & 1 & 3 & 2 & 1 & 1 & 1 & 1 & 1 & 1 & 1 & 1 & 1 & 2 & 1 & 18 \\
\hline Daun pocok/ager & 211 & 2 & 3 & 3 & 2 & 1 & 1 & 1 & 1 & 1 & 2 & 1 & 1 & 2 & 2 & 23 \\
\hline
\end{tabular}




\begin{tabular}{|c|c|c|c|c|c|c|c|c|c|c|c|c|c|c|c|c|}
\hline \multirow[b]{2}{*}{ Industri } & \multirow[b]{2}{*}{$\begin{array}{c}\text { Tot } \\
\text { Unit } \\
\text { Indus } \\
\text {-tri }\end{array}$} & \multicolumn{14}{|c|}{ Variabel/Dasar Pertimbangan Kompetensi Inti Industri } & \multirow[b]{2}{*}{$\begin{array}{l}\text { Total } \\
\text { skor }\end{array}$} \\
\hline & & $\begin{array}{c}\text { Kekha } \\
\text {-san }\end{array}$ & $\begin{array}{c}\text { Ba- } \\
\text { han } \\
\text { bak } \\
\text { u }\end{array}$ & $\begin{array}{c}\text { Asal } \\
\text { Peker } \\
\text {-ja }\end{array}$ & $\begin{array}{l}\text { Kade } \\
\text { risasi } \\
\text { SDM }\end{array}$ & $\begin{array}{l}\text { Tekno- } \\
\text { logi/ } \\
\text { Inovasi }\end{array}$ & $\begin{array}{l}\text { Komb } \\
\text { TK Vs } \\
\text { Mesin }\end{array}$ & $\begin{array}{l}\text { Kelem- } \\
\text { bagaan }\end{array}$ & Pasar & $\begin{array}{c}\text { Packa } \\
\text { ging }\end{array}$ & $\begin{array}{l}\text { Seg } \\
\text { me } \\
n\end{array}$ & $\begin{array}{l}\text { Dy } \\
\text { Ta } \\
\text { war } \\
\text { in- } \\
\text { put }\end{array}$ & $\begin{array}{c}\text { Dy } \\
\text { Ta } \\
\text { war } \\
\text { out } \\
\text { put }\end{array}$ & $\begin{array}{l}\text { Sek- } \\
\text { tor } \\
\text { hulu }\end{array}$ & $\begin{array}{l}\text { Sek- } \\
\text { tor } \\
\text { hilir }\end{array}$ & \\
\hline Tikar & 204 & 1 & 3 & 3 & 2 & 1 & 1 & 1 & 1 & 0 & 2 & 1 & 1 & 1 & 1 & 19 \\
\hline Anyaman Tikar & 164 & 2 & 3 & 3 & 2 & 1 & 1 & 1 & 1 & 1 & 2 & 1 & 1 & 1 & 1 & 21 \\
\hline Sangkar burung & 148 & 1 & 3 & 3 & 2 & 1 & 1 & 1 & 1 & 0 & 2 & 1 & 1 & 2 & 2 & 21 \\
\hline Kayu/ kayu arang & 51 & 0 & 3 & 2 & 2 & 1 & 1 & 1 & 1 & 0 & 2 & 1 & 1 & 1 & 1 & 17 \\
\hline Meubel & 51 & 1 & 2 & 2 & 1 & 1 & 1 & 1 & 1 & 0 & 2 & 1 & 1 & 2 & 1 & 17 \\
\hline Kapuk/kasur & 46 & 1 & 3 & 3 & 1 & 1 & 1 & 1 & 1 & 0 & 2 & 1 & 1 & 1 & 1 & 18 \\
\hline \multicolumn{17}{|c|}{ D. Semen, bahan galian non logam } \\
\hline Kapur & 191 & 1 & 3 & 3 & 1 & 1 & 1 & 1 & 1 & 0 & 2 & 1 & 1 & 1 & 1 & 18 \\
\hline Batu bata putih & 107 & 1 & 3 & 3 & 1 & 1 & 1 & 1 & 1 & 0 & 2 & 1 & 1 & 1 & 1 & 18 \\
\hline Genteng & 91 & 1 & 3 & 3 & 1 & 1 & 1 & 1 & 1 & 0 & 2 & 1 & 1 & 1 & 1 & 18 \\
\hline tanah liat/gerabah & 88 & 1 & 3 & 3 & 1 & 1 & 1 & 1 & 1 & 0 & 2 & 1 & 1 & 1 & 1 & 18 \\
\hline Bata merah & 60 & 1 & 3 & 3 & 1 & 1 & 1 & 1 & 1 & 0 & 2 & 1 & 1 & 1 & 1 & 18 \\
\hline \multicolumn{17}{|l|}{ E. Barang Lainnya } \\
\hline Jasa lasery & 24 & 0 & 1 & 3 & 1 & 1 & 1 & 1 & 1 & 0 & 2 & 1 & 1 & 1 & 1 & 15 \\
\hline Pecut & 49 & 2 & 2 & 3 & 2 & 1 & 1 & 1 & 1 & 1 & 2 & 1 & 1 & 2 & 2 & 22 \\
\hline & & & & & & & & & & & & & & & & \\
\hline
\end{tabular}




\begin{tabular}{|l|r|r|r|r|r|r|r|r|r|r|r|r|r|r|r|r|r|}
\hline Skor rata-rata & & 1 & 2 & 3 & 1 & 1 & 1 & 1 & 1 & 1 & 2 & 1 & 1 & 2 & 1 & 19 \\
\hline Standard deviasi (stdev) & & 0.61 & 0.99 & 0.50 & 0.41 & 0.00 & 0.00 & 0.00 & 0.00 & 0.79 & 0.18 & 0.00 & 0.00 & 0.61 & 0.38 & 1.90 \\
\hline Skor rata-rata + 1 stdev & & 2 & 3 & 3 & 2 & 1 & 1 & 1 & 1 & 2 & 2 & 1 & 1 & 2 & 2 & 21 \\
\hline Skor rata-rata + 2 stdev & & 2 & 4 & 4 & 2 & 1 & 1 & 1 & 1 & 2 & 2 & 1 & 1 & 3 & 2 & 22 \\
\hline Skor ideal & & 2 & 3 & 3 & 2 & 2 & 1 & 2 & 2 & 2 & 2 & 2 & 2 & 2 & 2 & Min 29 \\
\hline
\end{tabular}

Sumber: Hasil Olahan 
Jika kemudian ditentukan bahwa industri yang bisa dikatakan sebagai komptensi inti industri kabupaten Bangkalan adalah indutri yang berskor 21 atau lebih (sama atau lebih besar dari rata-rata skor ditambah satu standard deviasi skor seluruh industri), maka berikut ini adalah kompetensi inti industri Kabupaten Bangkalan: (1) Kripik/Krupuk terung; (2) batik tulis; (3) Tali agel; (4) anyaman tikar; (5) sangkar burung; (6) Industri pecut. Jika dijaring lagi, misalnya industri yang berskor sama atau lebih besar dari rata-rata ditambah dua kali standard deviasi skor industri yang ada (yaitu $\geq 22$ ), maka hanya tiga industri yang layak menjadi kompetensi inti industri Kabupaten Bangkalan, yaitu industri Kripik/Krupuk Terung, tali agel, dan pecut. Sementara itu, dua industri yang bisa dipertimbangkan untuk dijadikan kompetensi inti industri (memiliki skor kompetensi inti 20) adalah industri pengasapan/pengeringan ikan dan petis.

\section{KESIMPULAN}

Analisis terhadap potensi dan berbagai variabel kompetensi inti di Kabupaten Bangkalan menghasilkan kesimpulan bahwa industri yang menjadi kompetensi inti adalah industri kripik terung, tali Agel, Pecut, batik tulis, anyaman tikar dan sangkar burung. Sementara itu, industri yang dipertimbangkan sebagai kompetensi inti industri, yaitu pengasapan/pengeringan ikan dan pengolahan petis. Dengan demikian, kompetensi inti industri Kabupaten Bangkalan adalah industri berbahan baku hasil hutan (rakyat) dan perikanan.

Kompetensi inti industri di Kabupaten Bangkalan masih ditentukan oleh 'resource based industries' daripada 'market based industries'. Resource based industries berarti bahwa kompetensi inti industri lebih banyak ditentukan oleh potensi sumberdaya (resources) yang dibutuhkan dalam proses industri, utamanya bahan baku yang berasal dari sumberdaya alam dan sumberdaya manusia lokal. Sementara itu, market based industries berarti kompetensi inti industri lebih ditentukan oleh keunggulan produk industri tersebut di pasar. Dengan demikian, industri yang yang akan menjadi kompetensi inti adalah industri yang memiliki produk yang berdaya saing tinggi (sangat unggul) di pasar. 


\section{DAFTAR PUSTAKA}

Aurino. 2007. Keunggulan Berbasis Kompetensi dalam www.aurino.com

Badan Pusat Statistik Kabupaten Bangkalan. 2009. Bangkalan dalam Angka Tahun 2009.

Dinas Koperasi UMKM Kabupaten Bangkalan. 2008. Daftar Industri Mikro, Kecil dan Menengah (IMKM) dalam Studi Pengembangan IMKM Tahun 2008.

Dinas Perindustrian dan Perdagangan Kabupaten Bangkalan. 2008. Data Sentra Industri Kecil dan Menengah (IKM) Kabupaten Bangkalan Tahun 2008.

Dinas Perindustrian dan Perdagangan Kabupaten Bangkalan. 2008. Direktori Perusahaan Industri Kecil Menengah Kabupaten Bangkalan Tahun 2008.

Pemerintah Republik Indonesia. 1999. Undang-Undang No. 25 tahun 1992 tentang Perkoperasian.

Pemerintah Republik Indonesia. 2008. Peraturan Presiden no. 28 tahun 2008 tentang Kebijakan Industri Nasional.

Sekretaris Daerah Kota Singkawang. 2008. Setiap Daerah Memiliki Kompetensi Inti Industri dalam http:/ / humas.singkawangkota.go.id

Wanandriko. 2008. Pengertian, Tujuan, Kriteria dan Lingkup Produk One Village One Product dalam http://wanandriko.blogspot.com/2008/04/ovop-one-villageone-product.html 